Article

\title{
A Feasibility Study on the Application of Basic Oxygen Furnace (BOF) Steel Slag for Railway Ballast Material
}

\author{
Taehoon Koh ${ }^{1, *}$, Sung-Woo Moon ${ }^{2}$ (i), Hyuksang Jung ${ }^{3}$, Yeonung Jeong 4 (i) \\ and Sukhoon Pyo 1 id \\ 1 New Transportation Systems Research Center, Korea Railroad Research Institute, 176 Railroad \\ Museum Road, Uiwang-si, Gyeonggi-do 16105, Korea; shpyo@krri.re.kr \\ 2 Department of Civil Engineering, Nazarbayev University, 53 Qabanbay Batyr Ave, \\ Astana 010000, Kazakhstan; sung.moon@nu.edu.kz \\ 3 Department of Railroad Construction \& Safety Engineering, Dongyang University, 145 Dongyangdaero \\ Punggi-eup, Yeongju-si, Gyeongsangbuk-do 36040, Korea; yoricom@dyu.ac.kr \\ 4 Department of Civil and Environmental Engineering, National University of Singapore, 1 Engineering \\ Drive 2, Singapore 117576, Singapore; ceejeon@nus.edu.sg \\ * Correspondence: thkoh@krri.re.kr; Tel.: +82-31-460-5661
}

Received: 8 December 2017; Accepted: 20 January 2018; Published: 23 January 2018

\begin{abstract}
Railway ballast, for which natural crushed stone aggregates have been generally used, is an essential track component for the distribution of train loads along the rails and sleepers to the roadbed. However, the use of natural crushed stone aggregate causes environmental destruction as well as dust production in train service. This paper evaluates the feasibility of using the basic oxygen furnace (BOF) steel slag as railway ballast material. A series of physical and chemical quality tests are performed to investigate the characteristics of the materials associated with the effect of aging period due to the remaining free $\mathrm{CaO}$ and $\mathrm{MgO}$ in the $\mathrm{BOF}$ steel slag. Three different aging periods (i.e., 0,3 , and 6 months) are used to compare with various standards and the properties of the crushed stone aggregates. It is demonstrated that the physical and chemical properties of the BOF steel slag with different aging periods satisfy all requirements of standards sufficiently. Especially, the BOF steel slag without aging (i.e., 0 month) provides the similar physical and chemical properties, when compared to the BOF steel slag with aging (i.e., 3 and 6 months). Thus, it is possible to apply the BOF steel slag regardless of aging periods to the railway ballast materials instead of natural crushed stone aggregates.
\end{abstract}

Keywords: basic oxygen furnace (BOF) steel slag; electric arc furnace (EAF) steel slag; blast furnace (BF) iron slag; railway ballast; aging; free lime

\section{Introduction}

Generally, railway ballast helps distributing train loads along the rails and sleepers to the roadbed. Natural crushed stone aggregates which have similar engineering properties of concrete aggregates are widely employed as railway ballast materials. It is because the natural crushed stone aggregates reduce vibration as well as dust production in train service resulting from the cushioning effect of itself, and are easy to be installed. The performance of ballast layers essentially depends on the quality of the ballast materials, which is defined by the characteristics of individual particles (e.g., durability, shape, particle size distribution, weight of unit volume, absorption factor, and wear rate of particles).

For the currently used natural ballast, there are three problematic issues: (1) it is continuously exposed to abrasion and crush due to running train loading; (2) crushed or fragmented particles clogging the voids of the roadbed cause some problems with respect to the function of roadbed 
drainage systems; (3) both Multiple Tie Tamper (MTT) track maintenance works for track deformation and ballast cleaning lead to accelerating sudden settlements of the ballast layer. Thus, it is necessary to develop the eco-friendly and geo-engineered alternative ballast materials to provide improvement in stability during the ballasted track maintenance. Based on this background, this study aims to evaluate the feasibility of the steel slag as the railway ballast material to substitute for the natural ballast.

Steel industry slags, byproduct from iron and steel making, mainly consist of blast furnace (BF) iron slag, basic oxygen furnace (BOF) steel slag, and electric arc furnace (EAF) steel slag which have been actively used for various applications in construction. Namely, BF iron slag (air cooled BF slag and granulated BF slag) has long been utilized as a construction material (aggregate and concrete binder etc.), and steel slag (BOF slag and EAF oxidizing slag) has been the subject of numerous research efforts with the aim of used as aggregates for road, embankment, reinforced concrete elements, or high-performance concrete with good bond with reinforcements, eco-friendly prestressed concrete sleeper [1-4]. However, steel slag still has not been widely utilized as aggregate for concrete production limited by Construction Specification, due to its unqualified properties with the specification.

Recently, it was reported that the steel slag has been effectively used as railway ballast which is the largest component of the railway track by weight and by volume due to its advantages in construction as well as maintenance [5]. The National Slag Association (NSA) explained that steel industry slag could be excellent ballast material in several aspects: (1) higher durability than the quality standards, (2) cost effectiveness of sustainability and maintenance, and (3) minimum occurrence of mud pumping. Steel slag was applied to ballast materials for railways in the western region adjoining the California-Nevada border in United States [5].

Jones [6] described that coarse water-granulated BF slag and steel slag could be utilized as ballast materials for all railwayse including even high-speed railways, and fine-grained slag could be also used as a supplementary material to prevent the ballast from penetrating the roadbed layers. In addition, it was reported that the slag characteristics of angular and rough shapes stabilizes the track structure due to mutually interlocking. Therefore, it leads to: (1) stabilizing the uneven surface, (2) increasing the lateral resistance of track, (3) outstanding drainage performance, and (4) a high resistance to freezing and thawing [6].

For this intention, a series of physical and chemical tests in this study were performed for estimating engineering properties of the BOF slag as one of steel slags with three different aging periods (i.e., 0, 3, and 6 months), since remaining free $\mathrm{CaO}$ and $\mathrm{MgO}$ in the $\mathrm{BOF}$ slag may have an influence on its dimensional stability; free $\mathrm{CaO}$ causes expansion at early ages with the formation of $\mathrm{Ca}(\mathrm{OH})_{2}$ while free $\mathrm{MgO}$ makes expansion in long term period with the formation of $\mathrm{Mg}(\mathrm{OH})_{2}$. In addition, the test results were verified by the comparison with various standards and the natural ballast.

It is expected that over 20 million tons of the produced steel industry slag in Korea will be successfully recycled for the ballast materials annually. Thus, this study would contribute to: (1) environmental protection by substituting for the destruction of mountains to obtain the natural ballast, (2) enhancement of the track durability and drainage ability due to the outstanding wear resistance of the slag, and (3) increase of track stability due to the heavier weight of the track.

\section{Theoretical Background}

\subsection{Current Status of Steel Industry Slag Generat Ion and Recycling}

In 2016, the total amount of world crude steel production was approximately $1630 \mathrm{GN}$, and the average growth rates between years 2010 and 2015 was 2.5\% per annum [7]. Even though there is no exact data for world steel slag production, it is estimated that 1600 to $2400 \mathrm{GN}$ of steel slag are produced in 2016 over the world based on typical ratios of slag to steel output [8]. Thus, it should be noted that a substantial amount of byproducts have inevitably been produced from steelmaking industry.

However, it is also known that the steel industries have difficulty in coping with increasing costs for managing steel slag and securing the sites required for slag aging due to the lack of efficient 
processing methods and new demands. In addition, a large number of raw materials and energy are required and a variety of byproducts (e.g., BF slag, BOF slag, and EAF slag) are also produced in several processes such as iron-making, steelmaking, and rolling.

Figure 1 shows the total amount of steel industry slag divided into BOF slag and BF slag in major countries, including generated, imported and stored amounts [9-12]. The total amount of steel industry slag generated in United States was 153 GN in 2011, consisting of 80 GN of BF slag and 73 GN of BOF slag, as reported by the United States Geological Survey (USGS). The amount of steel industry slag produced in Japan was 383 GN in 2012, and the amount of BF slag (i.e., 246 GN) was produced much more than that of BOF slag (i.e., $137 \mathrm{GN}$ ).

Korea Iron and Steel Association (KOSA) described that more than $99 \%$ of the produced slag is recycled in various areas: (1) a raw material of cement (75\%), (2) civil engineering (15.9\%), (3) sub-base course materials for roads (5.2\%), and (4) fertilizers (2.7\%) [10].

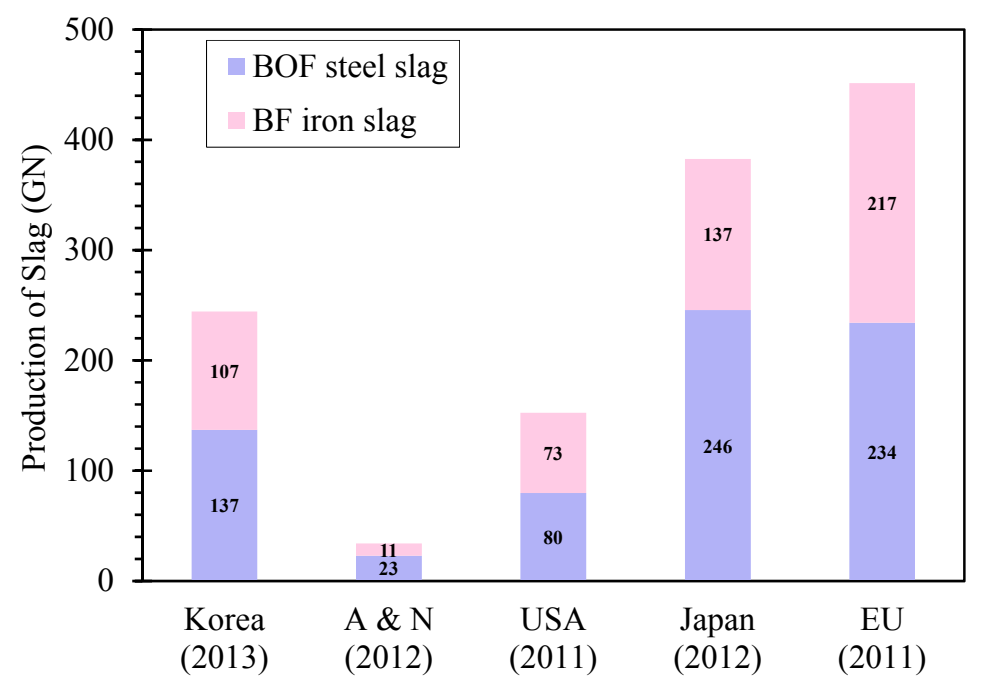

Figure 1. Generation of steel industry slag in major countries (Note: A \& N means Australia \& New Zealand).

\subsection{Standards for Railway Ballast Material}

In order to evaluate the test results conducted in this study, the following guidelines for ballast are considered as suggested by Korea Railroad Corporation Standard (KRCS) [13]: (1) unit weight of aggregates and solid content in aggregates; (2) abrasion and hardness of coarse aggregates by use of the Los Angeles machine; (3) compressive strength; and (4) immersion expansion in water, as presented in Table 1. Moreover, ballast is required to have the shape of a cube or polyhedron with rich edges and nearly identical facets, without harmful shapes such as a thin piece of stone.

As shown in Table 2, several standards for the evaluation of railway ballast materials are employed in Australia, the United States, Canada, and the United Kingdom, commonly adopting Los Angeles abrasion test. Thus, it indicates that the Los Angeles abrasion is the most critical element for the evaluation of ballast material, although there are differences of standards (i.e., 20-25\% in Australia, Canada, and the United Kingdom, $40 \%$ in the United States). 
Table 1. Quality standards for ballast [13].

\begin{tabular}{|c|c|c|c|}
\hline \multicolumn{2}{|c|}{ Classification } & Criteria & Test Methods \\
\hline \multicolumn{2}{|c|}{ Unit weight } & Higher than $14 \mathrm{kN} / \mathrm{m}^{3}$ & ASTM C29 \\
\hline \multicolumn{2}{|c|}{ Abrasion } & Less than $25 \%$ & ASTM C535-16 \\
\hline \multicolumn{2}{|c|}{ Hardness } & Higher than 20 & ASTM D2240 \\
\hline \multirow{2}{*}{\multicolumn{2}{|c|}{$\begin{array}{l}\text { Compressive strength } \\
\text { Immersion expansion }\end{array}$}} & Higher than $80 \mathrm{~N} / \mathrm{mm}^{2}$ & ASTM C170 \\
\hline & & Less than $1.5 \%$ & JIS A 5015 \\
\hline \multirow{3}{*}{$\begin{array}{c}\text { Contents of } \\
\text { harmful } \\
\text { materials }\end{array}$} & Clay & & ASTM C 142 \\
\hline & Coal and brown coal & Less than $3.5 \%$ & ASTM C123 \\
\hline & Soft fragments & & AASHTO T 189-70 \\
\hline
\end{tabular}

Table 2. Standards for physical properties of ballast material in major countries (Australia, the United States, Canada, and United Kingdom).

\begin{tabular}{cccccc}
\hline Ballast Property & Australia & USA & Canada & UK & Korea \\
\hline Aggregate Crushing Value & $<25 \%$ & - & - & $<22 \%$ & - \\
Los Angeles Abrasion & $<25 \%$ & $<40 \%$ & $<20 \%$ & $<20 \%$ & $<25 \%$ \\
Flakiness Index & $<30 \%$ & - & - & $<35 \%$ & - \\
Misshapen Particles & $<30 \%$ & - & $<25 \%$ & - & - \\
Sodium Sulphate & - & $<10 \%$ & $<5 \%$ & - & - \\
Soundness & - & $\mathrm{N} / \mathrm{A}$ & $<10 \%$ & - & - \\
Magnesium Sulphate & - & $<5 \%$ & $<5 \%$ & - & - \\
Soft and Friable Pieces & - & $<1 \%$ & $<1 \%$ & - & $<1 \%$ \\
Fines (<No. 200 sieve) & - & $<0.5 \%$ & $<0.5 \%$ & - & - \\
Clay Lumps & - & $>1120$ & - & - & $>1400$ \\
Bulk Unit Weight $\left(\mathrm{kg} / \mathrm{m}^{3}\right)$ & $>1200$ & - & $>2.6$ & - & - \\
Particle Specific Gravity & $>2.5$ & - & & &
\end{tabular}

\section{Physical and Chemical Quality Test Methods}

\subsection{Overivew}

Steel slag generally consists of free- $\mathrm{CaO}$, free- $\mathrm{MgO}$ (periclase), various types of crystalline phases such as olivine, merwinite, $\gamma-2 \mathrm{CaO} \cdot \mathrm{SiO}_{2}, 2 \mathrm{CaO} \cdot \mathrm{Fe}_{2} \mathrm{O}_{3}$, and $\mathrm{RO}$ phases $\left(\mathrm{CaO}-\mathrm{MgO}-\mathrm{SiO}_{2}-\mathrm{FeO}\right.$ solid solution) [14]. Depending on the steel manufacturing process (i.e., BOF and EAF) or cooling methods (i.e., natural drying and rapid cooling), it is proved that the chemical, physical and mineralogical properties are various. It is noted that free lime $(\mathrm{CaO})$ in the steel slag is from two different sources: (1) residual free lime originally contained in the raw materials, and (2) precipitated lime from the molten slag. The remaining free lime $(\mathrm{CaO})$ is known to react with water, transferring into Portlandite $\left[\mathrm{Ca}(\mathrm{OH})_{2}\right][14-17]$. This transformation induces $98 \%$ volumetric expansion of BOF slag [18]. In addition, free $\mathrm{MgO}$ in BOF slag also reacts with water, forming $\mathrm{Mg}(\mathrm{OH})_{2}$ with $148 \%$ of volumetric expansion. Moreover, Wang [17] and Wang et al. [19] illustrated that the volume of the BOF slag expands at least $7.5 \%$ with the expansive force (i.e., approximately $0.64-1.28 \mathrm{MPa}$ ).

The treatment of the free $\mathrm{CaO}$ and $\mathrm{MgO}$ contained in the $\mathrm{BOF}$ slag is a critical issue to apply the slag to the concrete aggregate due to the expansion characteristic (i.e., at least $7.5 \%$ of its original volume). Therefore, and the several aging methods, such as air aging treatment and steam aging method, have been employed [20-22]. It is necessary to consider the effects of aging to treat the free $\mathrm{CaO}$ and $\mathrm{MgO}$ in terms of physical and chemical quality of the BOF slag.

In this study, the BOF slag samples provided by a steelmaking company in Korea were used for the various tests up to six months to take into account the effects of aging. Typically, it is well-known that the recycled $\mathrm{BOF}$ slag requires at least six months for the aging process to reduce the expansion due to free $\mathrm{CaO}$ and $\mathrm{MgO}$ [22-24]. Therefore, the different periods of aging (i.e., 0, 3 and 6 months) were used for this study. The test results were evaluated by the comparison of the several standards. 
The chemical compositions of BOF slag samples tested in this study are as follows: $\mathrm{SiO}_{2} 14.3 \%$, $\mathrm{Al}_{2} \mathrm{O}_{3} 1.6 \%, \mathrm{CaO} 45.1 \%$, $\mathrm{Fe} 16.8 \%, \mathrm{MgO} 3.6 \%, \mathrm{MnO} 4.6 \%, \mathrm{TiO}_{2} 1.3 \%, \mathrm{~S} 0.2 \%$.

\subsection{Test Methods and Standards}

The basic physical properties as well as the quality of the BOF slag for railway ballast material were evaluated in six test methods for determining: (1) unit weight of aggregate (ASTM C29 [25]), (2) resistance to abrasion of coarse aggregate (ASTM C535 [26]), (3) hardness (ASTM D2240 [27]), (4) compressive strength (ASTM C170 [28]), (5) immersion expansion (JIS A 5015 [29]), (6) contents of harmful materials (ASTM C142 [30], ASTM C123 [31], AASHTO T 189-70 [32]).

The test method for unit weight of aggregate (ASTM C29 [25]) was conducted to measure the weight of a unit volume of the slag resulting from dividing the weight by the volume of the container.

The degree of ballast abrasion, which is one of the most critical factors, was evaluated by the abrasion test for coarse aggregate via the Los Angeles machine (ASTM C535 [26]). The test was performed by rotating the Los Angeles machine for each size of aggregate as a pre-defined number of rotations, and the number of 12 sieve and aggregate size of below $1.7 \mathrm{~mm}$ were used. Percentage amounts passing the No. $12(1.7 \mathrm{~mm})$ sieve due to abrasion were expressed in terms of original weight of the test sample before the test.

The hardness test (ASTM D2240 [27]) was performed by the shore hardness tester to measure the rebounding height of the hammer dropped on the test sample from a constant height. The shore hardness tester of the D-type model was employed to allow measuring the rebounding height of a diamond weight of $4 \mathrm{~g}$ dropped from the height of $25 \mathrm{~cm}$ with the test scale of 0 to 140 .

Unconfined compressive strength of the ballast is one of the most essential requirements because unqualified unconfined compressive strength causes crushed aggregate and excessive deformation of the ballast. The test method for unconfined compressive strength (ASTM C170 [28]) was carried out to determine the strength of the material expressed in terms of the compressive load divided by the cross-sectional area of the test sample. A test sample with dimensions of $5 \times 5 \times 5 \mathrm{~cm}^{3}$ made by aggregates (below $1.7 \mathrm{~mm}$ ) was placed under the displacement control test at a rate of $1 \mathrm{~mm} / \mathrm{min}$, as shown in Figure 2.

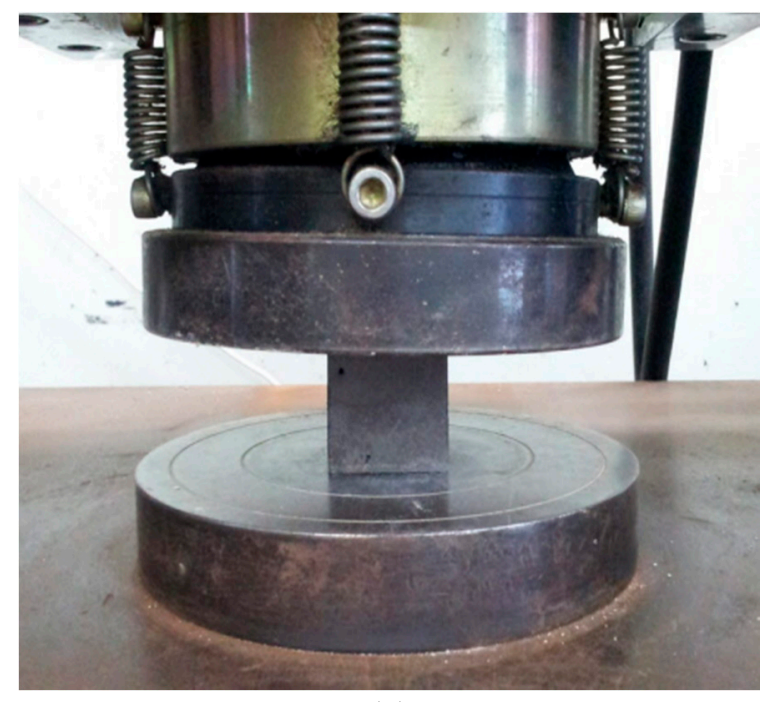

(a)

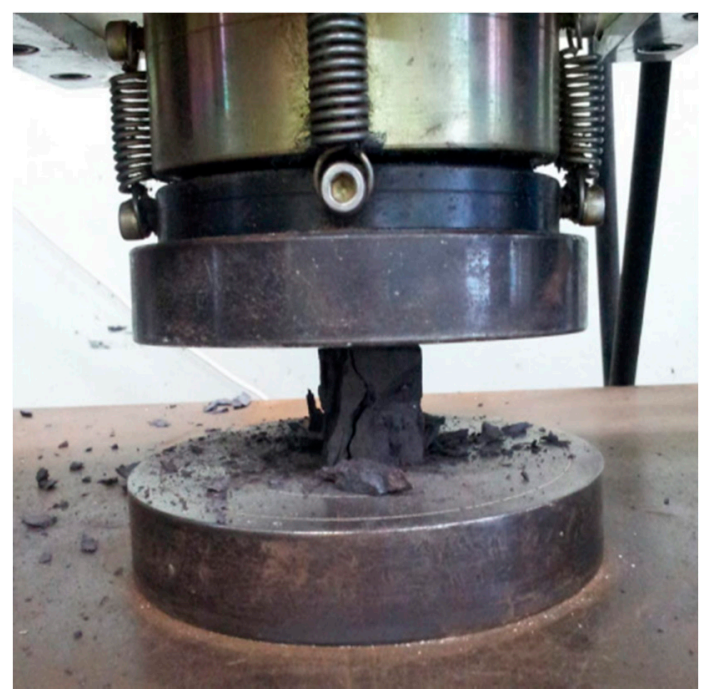

(b)

Figure 2. The test for unconfined compressive strength: (a) Before; (b) After. 
Figure 3 presents the immersion expansion test (JIS A 5015 [26]) that was implemented to evaluate the immersion expansion associated with remaining free $\mathrm{CaO}$ in $\mathrm{BOF}$ slag reacting on water, as follows:

$$
\begin{gathered}
\mathrm{CaO}+\mathrm{H}_{2} \mathrm{O} \rightarrow \mathrm{Ca}(\mathrm{OH})_{2}, \\
\mathrm{MgO}+\mathrm{H}_{2} \mathrm{O} \rightarrow \mathrm{Mg}(\mathrm{OH})_{2},
\end{gathered}
$$

The test sample adjusted by particle size was placed in three separate layers with the optimal moisture content based on the compaction test methods (ASTM D4792 [33]), and then the measurement device was installed. The test sample was maintained at the constant temperature of $70{ }^{\circ} \mathrm{C} \pm 3{ }^{\circ} \mathrm{C}$ for six hours, and the constant temperature was decreased to room temperature in the curing equipment. The test was conducted on a daily basis for 10 days. The immersion expansion ratio was estimated by the comparison of the final measurement and the initial measurement.

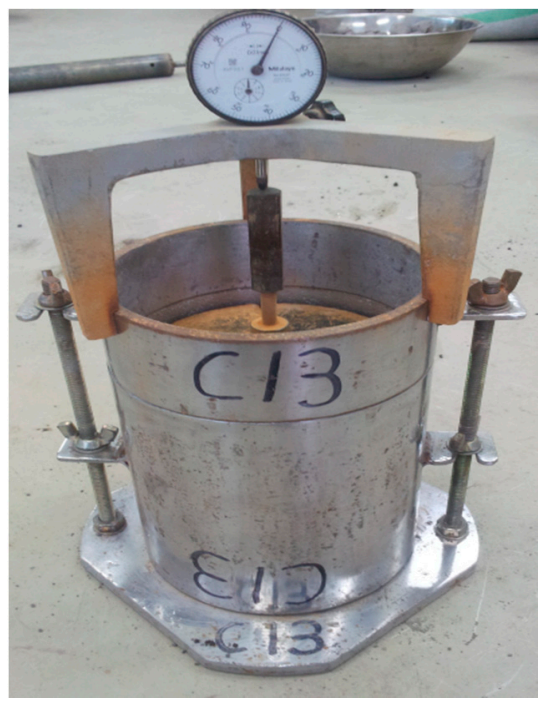

(a)

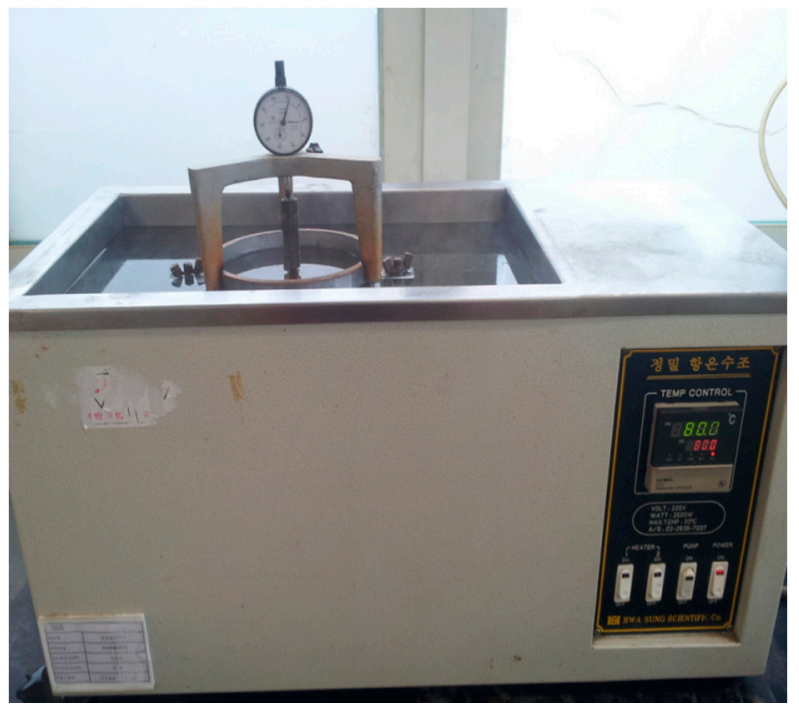

(b)

Figure 3. Immersion expansion test: (a) Preparing samples; (b) Immersion.

The harmful substances such as clay, coal and brown coal, and soft fragments, were evaluated by three different test methods (i.e., ASTM C142 [30], ASTM C123 [31], AASHTO T 189-70 [32]), and they should be less than $3.5 \%$ of the ballast samples. First, the test method for clay content (ASTM C142 [30]) was performed to determine the quantity of rock pieces which can be easily crushed due to harmful substances (e.g., a lump of clay) contained in the slag aggregate. Second, the test method for lightweight materials such as coal and brown coal included in the aggregate (ASTM C123 [31]) was employed to estimate the number of the harmful materials in the aggregate with bulk density lower than $20 \mathrm{kN} / \mathrm{m}^{3}$. The aggregate including the large number of lightweight materials is inapplicable to concrete structures and/or ballast requiring high strength. Third, the test method for the soft fragments of coarse aggregate (AASHTO T 189-70 [32]) was conducted to examine the degree of softness in the aggregate via scratch hardness. The use of coarse aggregates including a large number of soft or easily crushable particles leads to significant damages on the concrete properties, such as the hardness, elastic characteristics, and durability.

\section{Physical and Chemical Quality Test Results}

\subsection{Physical Quality Test Results}

Figure 4 presents the test results for determining the unit weight with three different aging periods. The unit weight of the BOF slag aggregate of 19.2 to $20.3 \mathrm{kN} / \mathrm{m}^{3}$ was calculated, and the average value 
of $19.7 \mathrm{kN} / \mathrm{m}^{3}$ is much larger than the KRCS requirement of $14.0 \mathrm{kN} / \mathrm{m}^{3}$. Since the difference of the unit weight between three different aging periods are $0.9 \mathrm{kN} / \mathrm{m}^{3}$, the aging effect on the unit weight is ignorable.

Compared to the natural aggregate of 15.5 to $16.5 \mathrm{kN} / \mathrm{m}^{3}$ (average value of $16.0 \mathrm{kN} / \mathrm{m}^{3}$ ), the BOF slag aggregate is approximately $23 \%$ heavier than the natural aggregate. Since it allows BOF slag railway ballast to get a higher resistance to the lateral pressure resulting from running trains, the BOF slag aggregate is more beneficial than the natural aggregate. As illustrated in Equation (3), the unit weight of sleeper has a significant influence on its lateral resistance, and the lateral resistance increases with increasing the unit weight. It is clearly appeared that the improved lateral resistance contributes to higher resistance against lateral pressure caused by the centrifugal force on curved tracks and a twisted railway track than natural aggregate.

$$
\mathrm{F}=\mathrm{a} \cdot \mathrm{W}+\mathrm{b} \cdot \gamma \cdot \mathrm{S}_{\mathrm{e}}+\mathrm{c} \cdot \gamma \cdot \mathrm{S}_{\mathrm{s}}
$$

F: Lateral resistance for each railway sleeper $(\mathrm{kg})$

$\mathrm{W}$ : Weight of railway sleeper $(\mathrm{kg})$

$\gamma$ : Unit weight of ballast $\left(\mathrm{kg} / \mathrm{cm}^{3}\right)$

$\mathrm{S}_{\mathrm{e}}$ : First moment on the end face of railway sleeper $\left(\mathrm{cm}^{3}\right)$

$\mathrm{S}_{\mathrm{s}}$ : First moment on the side face of railway sleeper $\left(\mathrm{cm}^{3}\right)$

a, b, c: Coefficients for each railway type (See Table 3).

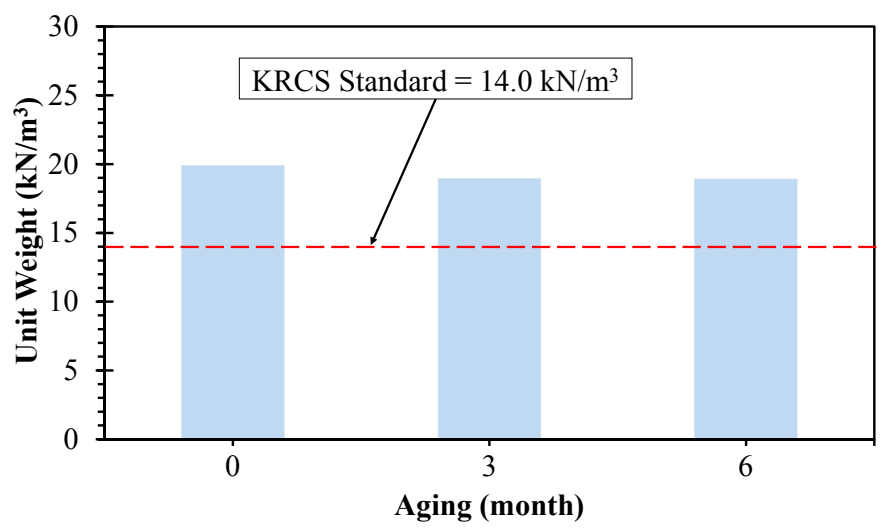

Figure 4. Unit weight test results with three different aging periods.

Table 3. Coefficients of Equation (3) depending on track types.

\begin{tabular}{cccc}
\hline Type & a & b & c \\
\hline PSC railway sleeper-crushed gravel & 0.75 & 29 & 1.8 \\
Wooden railway sleeper—crushed gravel & 0.75 & 29 & 1.3 \\
Wooden railway sleeper-worn gravel & 0.6 & 29 & 1.4 \\
\hline
\end{tabular}

Table 4 presents physical quality test results with different aging periods. Figure 5 shows the test results for abrasion with three different aging periods. The estimated wear rates of the BOF slag aggregate of 18.2 to $19.5 \%$ (average value of $18.7 \%$ ) satisfy the KRCS requirements which should be less than $25 \%$. Since the difference of the wear rates between three different aging periods were only $1.3 \%$, the aging effect on the abrasion was ignorable. It is expected that the abrasion resistance of the BOF slag aggregate is much higher than the natural aggregate, showing the wear rates of 21 to $27 \%$. Thus, the use of BOF slag aggregate as the ballast materials contributes to the effective maintenance management of railway ballast since much lower abrasion and crush of ballast material result in the decrease of mud pumping and the clogging of the roadbed. 
Table 4. Physical quality test results with different aging periods.

\begin{tabular}{|c|c|c|c|c|c|c|c|c|c|c|c|}
\hline \multirow{3}{*}{ Type } & \multicolumn{9}{|c|}{ Aging Periods (Month) } & \multirow{3}{*}{$\begin{array}{c}\text { Natural Railway } \\
\text { Ballast }\end{array}$} & \multirow{3}{*}{$\begin{array}{c}\text { KRCS } \\
\text { (2011) [10] }\end{array}$} \\
\hline & \multicolumn{3}{|c|}{$\mathbf{0}$} & \multicolumn{3}{|c|}{3} & \multicolumn{3}{|c|}{6} & & \\
\hline & $\begin{array}{l}\text { 1st } \\
\text { Trial }\end{array}$ & $\begin{array}{l}\text { 2nd } \\
\text { Trial }\end{array}$ & Ave. & $\begin{array}{c}\text { 1st } \\
\text { Trial }\end{array}$ & $\begin{array}{l}\text { 2nd } \\
\text { Trial }\end{array}$ & Ave. & $\begin{array}{l}\text { 1st } \\
\text { Trial }\end{array}$ & $\begin{array}{l}\text { 2nd } \\
\text { Trial }\end{array}$ & Ave. & & \\
\hline Unit weight $\left(\mathrm{kN} / \mathrm{m}^{3}\right)$ & 20.33 & 20.30 & 20.31 & 19.36 & 19.32 & 19.35 & 19.22 & 19.37 & 19.30 & $\begin{array}{c}15.50 \\
-16.50 \\
\end{array}$ & $\begin{array}{c}>14.0 \\
\left(\mathrm{kN} / \mathrm{m}^{3}\right)\end{array}$ \\
\hline Abrasion (\%) & 18.2 & 18.3 & 18.2 & 19.3 & 19.5 & 19.4 & 18.4 & 18.6 & 18.5 & $21 \sim 27$ & $<25(\%)$ \\
\hline Hardness (HS) & 60 & 65 & 63 & 68 & 69 & 69 & 64 & 66 & 65 & $40-50$ & $>20(\mathrm{HS})$ \\
\hline $\begin{array}{l}\text { Compressive strength } \\
\qquad\left(\mathrm{N} / \mathrm{mm}^{2}\right)\end{array}$ & 185 & 192 & 188 & 186 & 174 & 180 & 170 & 180 & 175 & $100-140$ & $\begin{array}{c}>80 \\
\left(\mathrm{~N} / \mathrm{mm}^{2}\right)\end{array}$ \\
\hline $\begin{array}{l}\text { Immersion expansion } \\
\text { in water }(\%)\end{array}$ & 0.84 & 0.83 & 0.84 & 0.86 & 0.85 & 0.86 & 0.56 & 0.60 & 0.58 & - & $<1.5(\%)$ \\
\hline
\end{tabular}

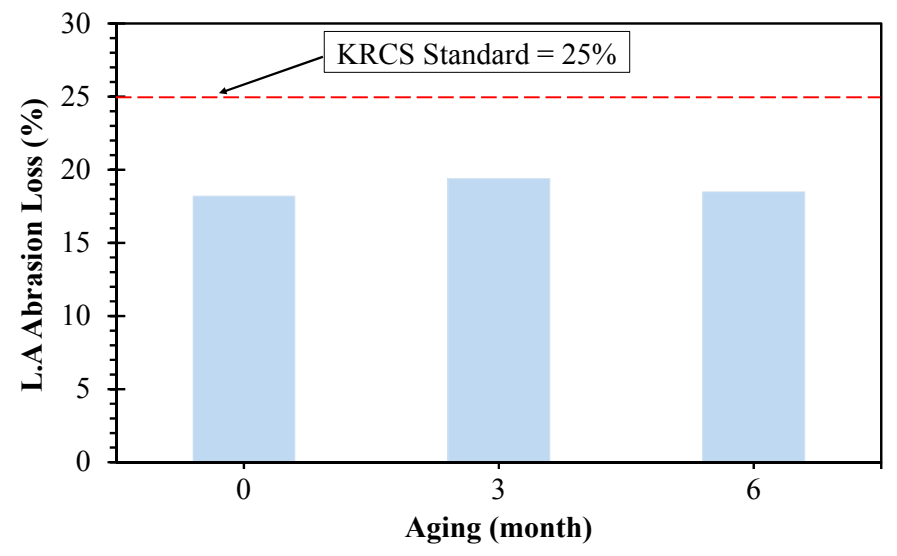

Figure 5. Abrasion test results with three different aging periods.

Figure 6 presents the test results of hardness with three different aging periods. The examined hardness (HS) of the BOF slag aggregate of 63 to 69 HS (average value of 66 HS) sufficiently satisfies the KRCS requirements which should be larger than $20 \%$. The test results show the aging effect on hardness can be ignored and hardness of the BOF slag aggregate is 30 to $40 \%$ larger than that of the natural aggregate.

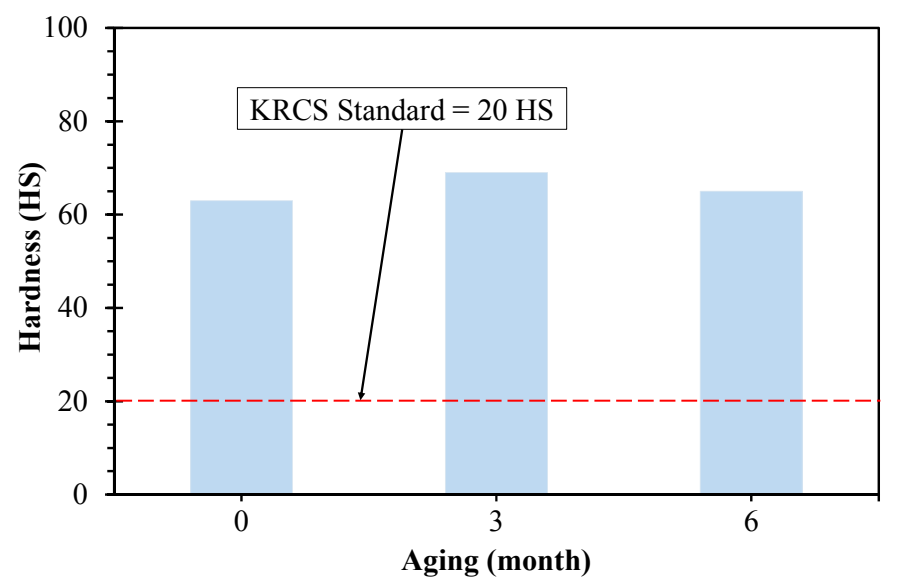

Figure 6. Hardness test results with three different aging periods.

Figure 7 shows the test results of the unconfined compressive strength with three different periods. The estimated unconfined compressive strength of the BOF slag aggregate was in a range of 175 to 
$188 \mathrm{~N} / \mathrm{mm}^{2}$ (average value of $183 \mathrm{~N} / \mathrm{mm}^{2}$ ). Since the test results were approximately $220 \%$ higher than the KRCS requirements $\left(80 \mathrm{~N} / \mathrm{mm}^{2}\right)$ and $125-188 \%$ higher than the unconfined compressive strength of the natural aggregate, the difference of the test results (i.e., $13 \mathrm{~N} / \mathrm{mm}^{2}$ ) with respect to the aging periods illustrates the aging effect on the unconfined compressive strength can be ignored.

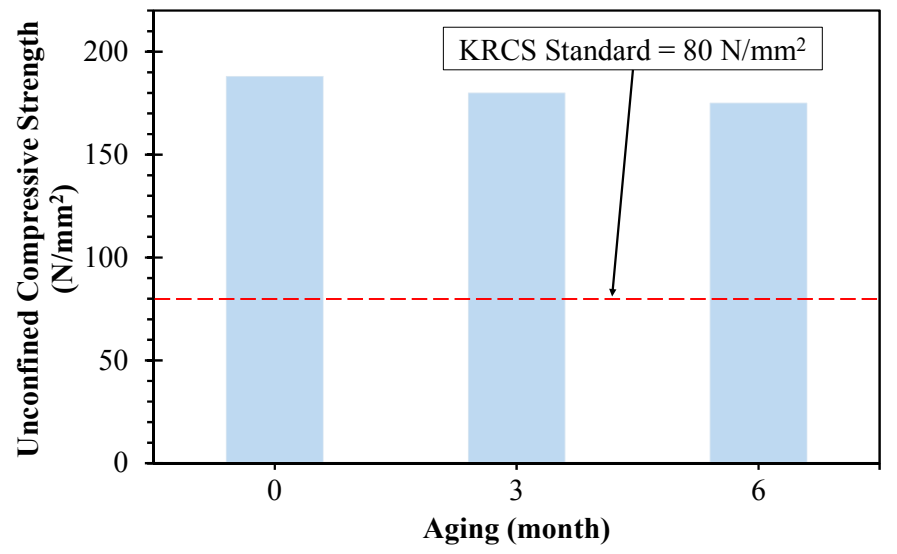

Figure 7. Unconfined compressive strength test results with three different aging periods.

The results of immersion expansion tests indicate that the immersion expansion ratio of the BOF slag with range of to 0.58 to $0.84 \%$ is much lower than the KRCS requirements (i.e., less than $1.5 \%$ ). However, further expansion from the transformation of free $\mathrm{MgO}$ to $\mathrm{Mg}(\mathrm{OH})_{2}$ may occur at long ages over a year because this chemical reaction slowly crops up. Thus, identifying free $\mathrm{MgO}$ content in the BOF slag is suggested before the actual use of the slag as a ballast material even though BOF slag aggregate constructed upon railway track has been continuously in the open-air aging state, and can be more stabilized.

Table 5 illustrates the test results for harmful substances in aggregates. From the test results, it was noted that the BOF slag did not contain any harmful (e.g., lead, mercury, organophosphorus compounds, tetrachlorethylene, trichloroethylene, and cyanogen), and included few quantities much less than criteria. It might be because such substances were burned by the high temperature during the steelmaking process. The absence of harmful substances in the BOF slag ballast makes it to be more stable than natural ballast including harmful substances.

Table 5. Chemical quality test results with different aging periods.

\begin{tabular}{ccccc}
\hline Item & \multirow{2}{*}{ Criteria } & \multicolumn{3}{c}{ Aging Periods (Month) } \\
\cline { 3 - 5 } & & $\mathbf{0}$ & $\mathbf{3}$ & $\mathbf{6}$ \\
\hline Lead & $<3 \mathrm{mg} / \mathrm{L}$ & N.D. & N.D. & N.D. \\
Copper & $<3 \mathrm{mg} / \mathrm{L}$ & N.D. & 0.003 & 0.007 \\
Arsenic & $<1.5 \mathrm{mg} / \mathrm{L}$ & N.D. & N.D. & 0.001 \\
Cadmium & $<0.3 \mathrm{mg} / \mathrm{L}$ & 0.007 & 0.009 & 0.006 \\
Mercury & $<0.005 \mathrm{mg} / \mathrm{L}$ & N.D. & N.D. & N.D. \\
Organophosphorus compounds & $<1 \mathrm{mg} / \mathrm{L}$ & N.D. & N.D. & N.D. \\
Tetrachlorethylene & $<0.1 \mathrm{mg} / \mathrm{L}$ & N.D. & N.D. & N.D. \\
Trichloroethylene & $<0.3 \mathrm{mg} / \mathrm{L}$ & N.D. & N.D. & N.D. \\
Cyanogen & $<1 \mathrm{mg} / \mathrm{L}$ & N.D. & N.D. & 0.35 \\
Hexavalent chromium & $<1.5 \mathrm{mg} / \mathrm{L}$ & N.D. & N.D. & 0.03 \\
Oil & $<5 \%$ & N.D. & N.D. & N.D. \\
\hline
\end{tabular}




\subsection{Chemical Quality Test Results}

Generally, BOF slag is considered as one of the industrial by-products, and it is essential to measure the content of each harmful substance in the BOF slag to satisfy the soil contamination standard for evaluating the suitability. The chemical quality test results showed that the slag was stable to be used for the ballast since the most harmful substances were not detected and even the detected harmful substances were very small amounts which were within criteria as indicated in Table 5.

\section{Conclusions}

This paper describes the feasibility of the application of BOF slag for railway ballast material by conducting physical and chemical quality tests based on standards. A variety of test results associated with the aging effect were evaluated by comparing with KRCS criteria and natural railway ballast. The following observations are made:

1. The unit weight of the BOF slag (i.e., average value of $19.7 \mathrm{kN} / \mathrm{m}^{3}$ ) was much higher than that of natural aggregate (i.e., average value of $16.0 \mathrm{kN} / \mathrm{m}^{3}$ ). Thus, it is expected that the BOF slag as the railway ballast material reveals higher resistance against lateral pressure caused by the centrifugal force on curved track than natural aggregate.

2. From abrasion and hardness tests, the wear rate of the BOF slag was approximately $25 \%$ lower than that of natural aggregate and hardness of the BOF slag was 30 to $40 \%$ larger than that of the natural aggregate. It appears that the BOF slag as the railway ballast material is beneficial in terms of the maintenance of a railway ballast due to a greater abrasion resistance and hardness under repeated train loading than that of currently used natural ballast.

3. From unconfined compressive tests, the test results presented that the unconfined compressive strength of the BOF slag was $220 \%$, and 125 to $188 \%$ larger than that of KRSC standard and natural aggregate, respectively. It is expected that the BOF slag as the railway ballast material reduces the particle breakage of coarse aggregates and excessive deformation of the railway ballast.

4. From the immersion expansion test, the produced expansion ratios of 0.58 to $0.84 \%$ sufficiently met the KRSC standard (i.e., less than $1.5 \%$ ).

5. For the aging effect, it was noted that three different aging periods had little effect on the changes of physical properties, and the aging effect can be ignored up to six months with the test sample. However, the steel slag may be expanded over long periods such as several years due to the expansion behavior of free $\mathrm{MgO}$, which could be considered as a future research topic.

6. For chemical quality test and the test for harmful substances in aggregates, no particular problems were detected in the test sample while further specific leaching test for the BOF slag could be considered as a future research topic to comply with environmental requirements before actual application of the BOF slag as railway ballast material.

It is demonstrated that the BOF slag is successfully applicable to the railway ballast since the test results cover the physical and chemical quality requirements. Especially, the BOF slag without an aging period (i.e., zero months) provides the similar physical and chemical properties compared to the BOF slag with aging periods (i.e., three and six months). Thus, it is possible to apply the BOF slag without aging to the railway ballast material instead of natural crushed stone aggregate. Nevertheless, the investigation for longer period expansion behavior of the steel slag would be regarded as a follow-up study with chemistry-based analysis because free $\mathrm{MgO}$ expansion generally occurs at long ages. More precision quality tests with environmental requirements can also support actual utilization of the BOF slag. The substitution of the BOF slag as the railway ballast material for the natural ballast material contributes to improving the quality of the ballast as well as reducing costs for the ballast maintenance if proper follow-up studies are conducted.

Acknowledgments: The research described herein was sponsored by a grant from R\&D Program of the Korea Railroad Research Institute, Republic of Korea. 
Author Contributions: Taehoon Koh and Sung-Woo Moon conceived and designed the experiments; Hyuksang Jung performed the experiments; Yeonung Jeong and Sukhoon Pyo analyzed the data; Taehoon Koh. and Sung-Woo Moon wrote the paper.

Conflicts of Interest: The authors declare no conflict of interest.

\section{References}

1. Koh, T.; Hwang, S. Field evaluation and durability analysis of an eco-friendly prestressed concrete sleeper. J. Mater. Civ. Eng. 2014, 27, B4014009. [CrossRef]

2. Faleschini, F.; Pellegrino, C. Experimental behavior of reinforced concrete beams with electric arc furnace slag as recycled aggregate. ACI Mater. J. 2013, 110, 197-206.

3. Faleschini, F.; Fernández-Ruíz, M.A.; Zanini, M.A.; Brunelli, K.; Pellegrino, C.; Hernández-Montes, E. High performance concrete with electric arc furnace slag as aggregate: Mechanical and durability properties. Constr. Build. Mater. 2015, 101, 113-121. [CrossRef]

4. Manso, J.M.; Polanco, J.A.; Losanez, M.; González, J.J. Durability of concrete made with EAF slag as aggregate. Cem. Concr. Compos. 2006, 28, 528-534. [CrossRef]

5. NSA. Steel Furnace Slag, an Ideal Railroad Ballast; Report NSA; National Slag Association: Pleasant Grove, UT, USA, 2001; p. 173.

6. Jones, R.T. Economic and environmentally beneficial treatment of slags in DC arc furnaces. In Proceedings of the VII International Conference on Molten Slags, Fluxes and Salts, Cape Town, South Africa, 25-28 January 2004; The South African Institute of Mining and Metallurgy: Johannesburg, South Africa, 2004; pp. 363-376.

7. Pellegrino, C.; Gaddo, V. Mechanical and durability characteristics of concrete containing EAF slag as aggregate. Cem. Concr. Compos. 2009, 31, 663-671. [CrossRef]

8. USGS. Mineral Commodity Summaries 2017; US Geological Survey: Reston, VA, USA, 2017; p. 202.

9. ASA. Available online: http://www.asa-inc.org.au (accessed on 22 January 2018).

10. KOSA. Available online: http:/ / www.kosa.or.kr (accessed on 22 January 2018).

11. NSA. Available online: http:/ / www.slg.jp/e (accessed on 22 January 2018).

12. USGS. Available online: http:/ / www.usgs.gov (accessed on 22 January 2018).

13. Korea Rail Corporation Standard-Railway Ballast Material, KRCS A015 04. 2011; 1-11. (In Korean)

14. Yildirim, I.Z.; Prezzi, M. Use of Steel Slag in Subgrade Applications; FHWA/IN/JTRP-2009-32/SPR-3129, Joint Transportation Research Program; Purdue University: West Lafayette, IN, USA, 2009.

15. Ramachandran, V.S.; Sereda, P.J.; Feldman, R.F. Mechanism of hydration of calcium oxide. Nature 1964, 201, 288-299. [CrossRef]

16. Shi, C. Steel Slag - Its Production, Processing, Characteristics, and Cementitious Properties. J. Mater. Civ. Eng. 2004, 16, 230-236. [CrossRef]

17. Wang, G. Determination of expansion force of steel slag coarse aggregate. Constr. Build. Mater. 2010, 24, 1961-1966. [CrossRef]

18. Zhao, J.; Yan, P.; Wang, D. Research on mineral characteristics of converter steel slag and its comprehensive utilization of internal and external recycle. J. Clean. Prod. 2017, 156, 50-61. [CrossRef]

19. Wang, G.; Yuhong, W.; Zhili, G. Use of steel slag as a granular material: Volume expansion prediction and usability criteria. J. Hazard. Mater. 2010, 183, 555-560. [CrossRef] [PubMed]

20. Kalyoncu, R.S. Slag-Iron and Steel; US Geological Survey Minerals Yearbook; USGS: Reston, VA, USA, 2001.

21. Moon, H.Y.; Yoo, J.H. Effect of Aging Process to Use Steel Slag for Concrete Aggregate. In Proceedings of the 6th International Symposium of East Asian Resources Recycling Technology, Gyeongju, Korea, 23-25 October 2001; pp. 520-525.

22. Sasaki, T.; Hamazaki, T. Development of Steam-Aging Process for Steel Slag; Nippon Steel \& Sumitomo Metal Technical Report; Nippon Steel \& Sumitomo Metal: Tokyo, Japan, 2015; pp. 23-26.

23. Dziarmagowski, M. Possibilities of converter slag utilization. Arch. Metall. Mater. 2005, 50, 769-782.

24. Mihok, L.; Demeter, P.; Baricova, D.; Seilerova, K. Utilization of ironmaking and steelmaking slags. Metalurgija 2006, 45, 163-168.

25. Standard Test Method for Bulk Density ("Unit Weight") and Voids in Aggregate; ASTM C29/C29M-17a; ASTM International: West Conshohocken, PA, USA, 2017. 
26. Standard Test Method for Resistance to Degradation of Large-Size Coarse Aggregate by Abrasion and Impact in the Los Angeles Machine; ASTM C535-16; ASTM International: West Conshohocken, PA, USA, 2016.

27. Standard Test Method for Rubber Property_Durometer Hardness; ASTM D2240-15; ASTM International: West Conshohocken, PA, USA, 2015.

28. Standard Test Method for Compressive Strength of Dimension Stone; ASTM C170/C170M-17; ASTM International: West Conshohocken, PA, USA, 2017.

29. Iron and Steel Slag for Road Construction; JIS A 5015; Japanese Standards Association: Tokyo, Japan, 2013.

30. Standard Test Method for Clay Lumps and Friable Particles in Aggregates; ASTM C142/C142M-17; ASTM International: West Conshohocken, PA, USA, 2017.

31. Standard Test Method for Clay Lumps and Friable Particles in Aggregates; ASTM C123/C123M-14; ASTM International: West Conshohocken, PA, USA, 2014.

32. Standard Method of Test for Scratch Hardeness of Coarse Aggregate Particles; AASHTO T 189-70; American Association of State Highway and Transportation Officials: Washington, DC, USA, 1982.

33. Standard Test Method for Potential Expansion of Aggregates from Hydration Reactions; ASTM D4792/D4792M-13; ASTM International: West Conshohocken, PA, USA, 2013.

(C) 2018 by the authors. Licensee MDPI, Basel, Switzerland. This article is an open access article distributed under the terms and conditions of the Creative Commons Attribution (CC BY) license (http:/ / creativecommons.org/licenses/by/4.0/). 